\title{
EFFECT OF BETAMETHASONE AND DICLOFENAC SODIUM ON SERUM AND TISSUE CONCENTRATION OF AMOXICILLIN. In vivo STUDY IN RATS
}

\author{
EFEITO DA BETAMETASONA E DO DICLOFENACO SÓDICO NA CONCENTRAÇÃO \\ SÉRICA E TECIDUAL DA AMOXICILINA. ESTUDO in vivo EM RATOS
}

\author{
Thales Rocha MATTOS FILHO ${ }^{1}$, Marcelo de Souza JUNQUEIRA ${ }^{1}$, Francisco Carlos GROPPO ${ }^{1}$, \\ Rogério Heládio Lopes MOTTA², Fábio Ferreira PERAZZO ${ }^{3}$
}

\author{
1- DDS. MSc, PhD,Department of Pharmacology, Anesthesiology and Therapeutics, Piracicaba Dental School - UNICAMP, SP, Brazil \\ 2- DDS, MSc, PhD, Department of Pharmacology, Anesthesiology and Therapeutics, São Leopoldo Mandic Dental School, Campinas, SP, \\ Brazil \\ 3- Pharm, MSc, PhD, Pharmacy Laboratory, University Campi “Marco Zero do Equador” Macapá, AP, Brazil.
}

Corresponding address: Prof. Dr. Francisco Carlos Groppo, Av Limeira 901, Bairro Areião - Piracicaba, São Paulo, Brazil - ZIP $13414-903$ e-mail: fcgroppo@fop.unicamp.br - Tel: 19 3412-5310 - Fax: 19 3421-0144.

Received: July 1, 2005 - Modification: April 10, 2006 - Accepted: August 31, 2006

\begin{abstract}
Q bjective: Antimicrobial agents in combination with anti-inflammatory drugs have been usually prescribed in both Medicine and Dentistry. However, few scientific reports support this clinical practice. The aim of this study was to evaluate the effect of betamethasone and diclofenac sodium on serum and tissue concentration of amoxicillin in rats. Methods: Four polyurethane sponges were implanted in the back skin of 48 rats. After seven days the animals were divided into 6 groups (n=8). Group 1: amoxicillin (25 mg/kg); G2: diclofenac sodium $(2.5 \mathrm{mg} / \mathrm{kg})$; G3: betamethasone (0.1 mg/kg); G4: diclofenac sodium and amoxicillin; G5: betamethasone and amoxicillin; and G6: 0.9\% sodium chloride solution (1.0 mL - control group). All drugs were administered in a single dose. After 90 minutes, the granulomatous tissues of each animal were surgically removed and weighed. Blood was collected from cervical plexus, centrifuged and $10 \mu \mathrm{L}$ of serum was placed on paper discs. In order to estimate amoxicillin concentration, serum and granulomatous tissues were separately submitted to microbiological assay, which used $10^{8} \mathrm{cfu} / \mathrm{mL}$ of Staphylococcus aureus ATCC 25923 (penicillin-susceptible strain). After incubation (18 hours, $37^{\circ} \mathrm{C}$ ) the inhibition zones were measured and compared to a regression curve. Results: No inhibition zones were observed for groups 2, 3 and 6 . Tissue and serum concentrations of both G1 $(4.14 \mu \mathrm{g} / \mathrm{g}$ and $2.06 \mu \mathrm{g} / \mathrm{mL}$, respectively) and G5 (3.87 $\mu \mathrm{g} / \mathrm{g}$ and $1.70 \mu \mathrm{g} / \mathrm{mL}$, respectively) showed statistically significant differences (Kruskal-Wallis, $\mathrm{p}<0.05)$ in comparison to G4 (1.45 $\mathrm{g} / \mathrm{g}$ and $0.41 \mu \mathrm{g} / \mathrm{mL}$, respectively). G1 and G5 did not differ significantly ( $>0.05$ ). Conclusion: Considering single doses, betamethasone did not interfere with amoxicillin levels but diclofenac sodium reduced both tissue and serum levels of amoxicillin in rats.

Uniterms: Amoxicillin; Betamethasone; Drug interaction.
\end{abstract}

\begin{abstract}
RESUMO
O bjetivo: A prescrição de antimicrobianos associados a antiinflamatórios é uma prática comum em odontologia, embora na maioria das vezes não haja justificativa para tal conduta. O objetivo deste trabalho foi avaliar, em um estudo in vivo em ratos, os efeitos da betametasona e do diclofenaco sódico nas concentrações sérica e tecidual da amoxicilina. Métodos: Foram utilizados 48 ratos Wistar machos (6 grupos, $\mathrm{n}=8$ ), com idade de 60 dias. Esponjas de PVC (policlorovinil) foram implantadas em quatro pontos no dorso de cada animal. Após sete dias, foram administrados por via intragástrica ou intramuscular: Grupo 1: amoxicilina (25 mg/kg); G2: diclofenaco sódico (2,5 mg/kg/i.m.); G3: betametasona (0,1 mg/kg/i.m.); G4: diclofenaco sódico e amoxicilina; G5: betametasona e amoxicilina; e G6: solução de cloreto de sódio a 0,9\% (1,0 mL - grupo controle). Após 90 minutos, foram colhidos 2 tecidos granulomatosos e amostras séricas de cada animal e colocados em meios de cultura inoculados com $10^{8}$ ufc/mL de Staphylococcus aureus ATCC 25923. Os halos de inibição foram medidos após 18 horas de incubação $\left(37^{\circ} \mathrm{C}\right)$, e através do teste microbiológico foram obtidas as concentrações séricas e teciduais da amoxicilina. Resultados: Não

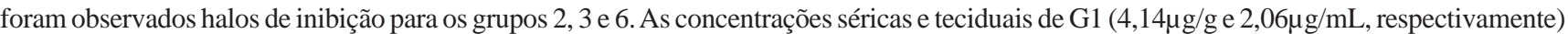

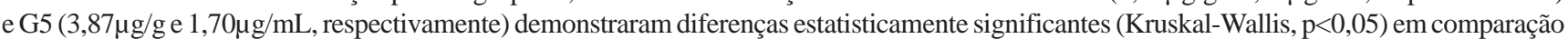

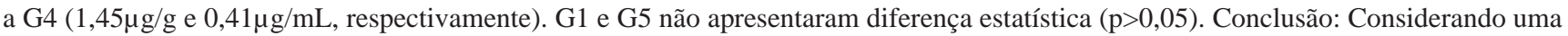
dose única, a betametasona não interferiu nas concentrações sérica e tecidual de amoxicilina, enquanto o diclofenaco sódico reduziu as concentrações sérica e tecidual de amoxicilina em ratos.
\end{abstract}

Unitermos: Amoxicilina; Betametasona; Interação medicamentosa. 


\section{INTRODUCTION}

Amoxicillin is a widely prescribed aminopenicillin, primarily for oral use $\mathrm{e}^{22}$. It has been used as the first choice in several odontogenic infections and bacterial endocarditis prophylaxis. The standard bacterial endocarditis prophylaxis regimen includes a 2-g single dose of amoxicillin, one hour before the procedure?

The oral daily recommended dosage for adult patients is usually 250 to $500 \mathrm{mg}$ TID $^{9}$ or 875 to $1000 \mathrm{mg} \mathrm{BID}^{4}$. For pediatric patients, depending on the infection severity and the etiological agent, the dosage is usually 25 to $50 \mathrm{mg} / \mathrm{kg}$ $\mathrm{TID}^{1,8}$.

Amoxicillin has been also frequently used in Dentistry as a substitute for phenoxymethylpenicillin and ampicillin due to a better oral absorption and larger period of time between doses. Food does not interfere with either absorption or plasma concentration of amoxicillin ${ }^{6}$.

Ninety percent of the administered dose of amoxicillin is absorbed without molecular modifications ${ }^{13}$ providing serum concentration ranging from $7.6 \mu \mathrm{g} / \mathrm{mL}$ to $10.8 \mu \mathrm{g} / \mathrm{mL}$ after $500 \mathrm{mg} /$ po dose in human beings ${ }^{10}$. In rats, serum concentration ranged from $28 \mu \mathrm{g} / \mathrm{mL}$ and $13 \mu \mathrm{g} / \mathrm{mL}$ when 40 $\mathrm{mg} / \mathrm{kg} / \mathrm{po}$ and $7.0 \mathrm{mg} / \mathrm{kg} / \mathrm{po}$ of amoxicillin were administered, respectively ${ }^{3,11}$.

Approximately $60 \%$ of oral doses of amoxicillin are excreted in the urine in unchanged form within six hours by glomerular filtration (to a limited extent) and tubular secretion ${ }^{16}$. PEPT1 (in intestine) and PEPT2 (in kidney) are $\mathrm{H}^{+}$-coupled peptide transporters that mediate and limit the transport of amoxicillin ${ }^{27}$. Other drugs that have affinity for these transporters could interfere with amoxicillin bioavailability.

Antimicrobial agents help the host immune system to kill bacteria. The phagocytic cells are a major component of host resistance against bacteria and any drug that impairs their function is likely to increase susceptibility to infection ${ }^{21}$. However, the modulation of the inflammatory response of infectious diseases could be beneficial since the sequelae relate, in part, to this reaction ${ }^{23}$.

The association of antimicrobial and anti-inflammatory agents is relatively common in Dentistry and in Medicine. This association has been used routinely for prevention of infection along with the use of corticosteroids, for example. However, there are few studies regarding the effects of this association ${ }^{2}$.

Dexamethasone has been used together with different antibiotics in the treatment of experimental staphylococcal endophthalmitis ${ }^{31}$, and septic nephritis ${ }^{29}$. Siaperas, et al. ${ }^{25}$ (2001) observed that dexamethasone $(0.5 \mathrm{mg} / \mathrm{kg}$, BID) used together with vancomycin (30mg/kg every $12 \mathrm{~h}$, IV) reduced the tissue damage of the aortic valves in experimental staphylococcal endocarditis and did not affect the antimicrobial agent effectiveness.

In a rat model, the combination therapy with antibiotics and steroids was also more effective to reduce, or even to prevent, the persistence of ear mucosal changes in acute otitis media than the administration of antibiotics alone ${ }^{19}$.
However, one of the main side effects of anti-inflammatory drugs, particularly corticosteroids, is the impairment of cellular defenses against infection. The reactivation of latent infections by corticosteroids has proven to be a clinical problem $^{21}$.

Non-steroidal anti-inflammatory drugs do not prevent the synthesis of leukotriene B4 (a potent endogenous chemotactic factor), which could explain why therapeutic doses of aspirin-like drugs have little or no effect on leukocyte accumulation and activation during the inflammatory phenomenon ${ }^{21}$. As well as corticosteroids, there are very few studies about the concomitant use of these anti-inflammatory drugs and antimicrobial agents.

Drug interactions between amoxicillin and diclofenac sodium were previously demonstrated in the literature ${ }^{12}$. This study showed that both amoxicillin tissue and serum concentrations were significantly reduced by diclofenac sodium.

Being the corticosteroids one of the most used antiinflammatory agents in dentistry when a significant amount of surgical trauma is expected ${ }^{2}$, the purpose of this study was to verify the effect of betamethasone on serum and tissue concentrations of amoxicillin.

\section{MATERIALAND METHODS}

Bacterial strain. A penicillin-sensible Staphylococcus aureus strain (ATCC 25923) was used for the in-vitro test to determine the MIC and MBC $_{100}$ by using Mueller-Hinton broth (Merck, Darnstadt, Germany) and Salt Mannitol agar (Merck, Darnstadt, Germany), respectively. The same strain was used to carry out the regression line assay and the microbiological assay of amoxicillin concentrations.

Drugs. Amoxicillin trihydrate was obtained from Sigma Chemical Co. (St Louis, MO, U.S.A.). Betamethasone (Celestone injectable ${ }^{\circledR}$ - Schering-Plough S/A) and diclofenac sodium (Voltaren injectable ${ }^{\circledR}$ - Novartis Biociências) were commercially obtained. Physiological saline solution $(0.9 \% \mathrm{NaCl})$ was administered to the control animals.

Animals. Forty-eight adult male Wistar rats (Rattus norvegicus- albinus), aged 60 days and weighing $175 \pm 25$ g, were obtained from CEMIB-UNICAMP (Centro de Bioterismo-ICLAS Monitoring/Reference Center, Campinas, Brazil) where they were maintained under aseptic conditions. The Institutional Review Board for Ethics in Animal Research of University of Campinas approved all procedures (protocol \#423-1).

Granulomatous tissue model. All animals were anesthetized with a combination of ketamine $90 \mathrm{mg} / \mathrm{kg} / \mathrm{i} . \mathrm{m}$., and xylazine $10 \mathrm{mg} / \mathrm{kg} / \mathrm{i} . \mathrm{m} .{ }^{28}$ and granulomatous tissue was induced as previously described ${ }^{3,12}$. Briefly, four sterilized polyurethane sponge discs (density $35 \mathrm{~kg} / \mathrm{m}^{3}$ ) were subcutaneously implanted in the back of all rats. These sponge discs (Proespuma Com. \& Ind. Ltd., São Paulo, Brazil) were $12 \mathrm{~mm}$ in diameter and $5 \mathrm{~mm}$ thick, weighing $12.1 \pm 0.81 \mathrm{mg}$.

Experimental groups. Seven days after the sponge 
introduction, all animals were assigned into six groups of eight animals each: G1 - amoxicillin 25 mg/kg/p.o.; G2 diclofenac sodium $2.5 \mathrm{mg} / \mathrm{kg} / \mathrm{i} . \mathrm{m}$.; G3 - betamethasone 0.1 mg/kg/i.m.; G4 - amoxicillin 25 mg/kg/p.o. and diclofenac sodium $2.5 \mathrm{mg} / \mathrm{kg} / \mathrm{i} . \mathrm{m} . ;$ betamethasone $0.1 \mathrm{mg} / \mathrm{kg} / \mathrm{i} . \mathrm{m}$.; and G6 - physiological saline $(0.9 \% \mathrm{NaCl}) 1.0 \mathrm{~mL} / \mathrm{p} .0$. All drugs were administered in a single dose.

Surgical and sampling procedures. After $90 \mathrm{~min}$ of drug administration, blood samples were collected by cutting the carotid plexus of each animal under general anesthesia.

Blood samples were centrifuged and $10 \mu \mathrm{L}$ of serum was placed on three sterilized paper discs $(6.25 \mathrm{~mm})$ and dried at room temperature. Granulomatous tissues were delimited and surgically removed. All discs and two granulomatous tissue samples of each animal were placed on Muller-Hinton Agar plates inoculated with $10^{8} \mathrm{cfu} / \mathrm{mL}$ of $S$. aureus. After 18 hours of incubation at $37^{\circ} \mathrm{C}$, the inhibition zones were measured. Two granulomatous tissue samples of each animal were weighed and analyzed by a histological routine technique (HE). Granulomatous tissue weights, tissue and serum concentrations were submitted to the Kruskal-Wallis test and Dunn test (software Bioestat $1.0^{\circledR}$ for Windows ${ }^{\odot}$ ) in order to compare all groups.

Regression line: Amoxicillin suspensions of 0.03, 0.05, 0.07, 0.10, 0.30, 0.50, 0.70, 1.0, 3.0, 5.0, 7.0 and $10 \mu \mathrm{g} / \mathrm{mL}$ were made by using drug-free serum of rats and $10 \mu \mathrm{L}$ were placed onto dry paper-filter discs (6.25 mm). Three discs of each concentration were placed on the Mueller Hinton agar, previously inoculated with $10^{8} \mathrm{cfu} / \mathrm{mL}$ of $S$. aureus. The resulting inhibition zones were measured (mm) after 18 hours of incubation at $37^{\circ} \mathrm{C}$. These zones and the amoxicillin concentrations were used to obtain the regression line (Excel $\mathrm{XP}^{\circledR}$ - Microsoft Corporation).

\section{RESULTS}

MIC and $\mathrm{MBC}_{100}$ of amoxicillin against S. aureus ATCC 25923 were respectively $0.2 \mu \mathrm{g} / \mathrm{mL}$ and $1.5 \mu \mathrm{g} / \mathrm{mL}$.

The limits of detection of the regression curve were $0.03 \mu \mathrm{g} / \mathrm{mL}$ (12 mm of inhibition zone diameter) and $10 \mu \mathrm{g} / \mathrm{mL}$ (31 mm of inhibition zone diameter). The relation between the diameter of inhibition zone (DIZ - in mm) and the concentration of amoxicillin $(\mathrm{CA}$ - in $\mu \mathrm{g} / \mathrm{mL})$ was DIZ $=(3.23$ $x \operatorname{Ln}(C A))+24.16$, which showed a coefficient of regression (R) of 0.9851 . This relation was used to estimate tissue and serum concentrations, considering the mean of tissue weights of each animal.

The wet weight (mg) values (mean \pm s.e.m.) of the granulomatous tissue samples were 30.25 ( \pm 1.98$), 42.81$ ( \pm 3.26), 40.25 ( \pm 1.98$), 31.25$ ( \pm 2.58$), 46.5$ ( \pm 3.8$)$ and 41.19 ( \pm 2.22 ), respectively for groups $1,2,3,4,5$ and 6 . No statistically significant differences were observed among groups ( $>0.05$ ) regarding the wet weight values.

After 7 days and 90 minutes, a delimited fibrous capsule involving the sponge was observed in all samples. Fibroblasts, mesenchymal cells, and new capillary formation were verified in large scale. Infectious exudate was not observed in any of the granulomatous tissues.

Figure 1 shows amoxicillin serum and tissue concentrations of groups 1, 4 and 5. Groups 2, 3 and 6 did not show any inhibition zone considering both serum and tissue samples during the microbiological assay. Just the groups that used amoxicillin showed these inhibition zones. Amoxicillin serum and tissue concentration were not significantly ( $p>0.05$ ) affected by betamethasone. However, diclofenac sodium induced a reduction in both serum and tissue amoxicillin concentrations $(\mathrm{p}<0.05)$.

\section{DISCUSSION}

MIC and $\mathrm{MBC}_{100}$ of amoxicillin against S. aureus ATCC 25923 strain confirmed its susceptibility ${ }^{14}$. As observed in

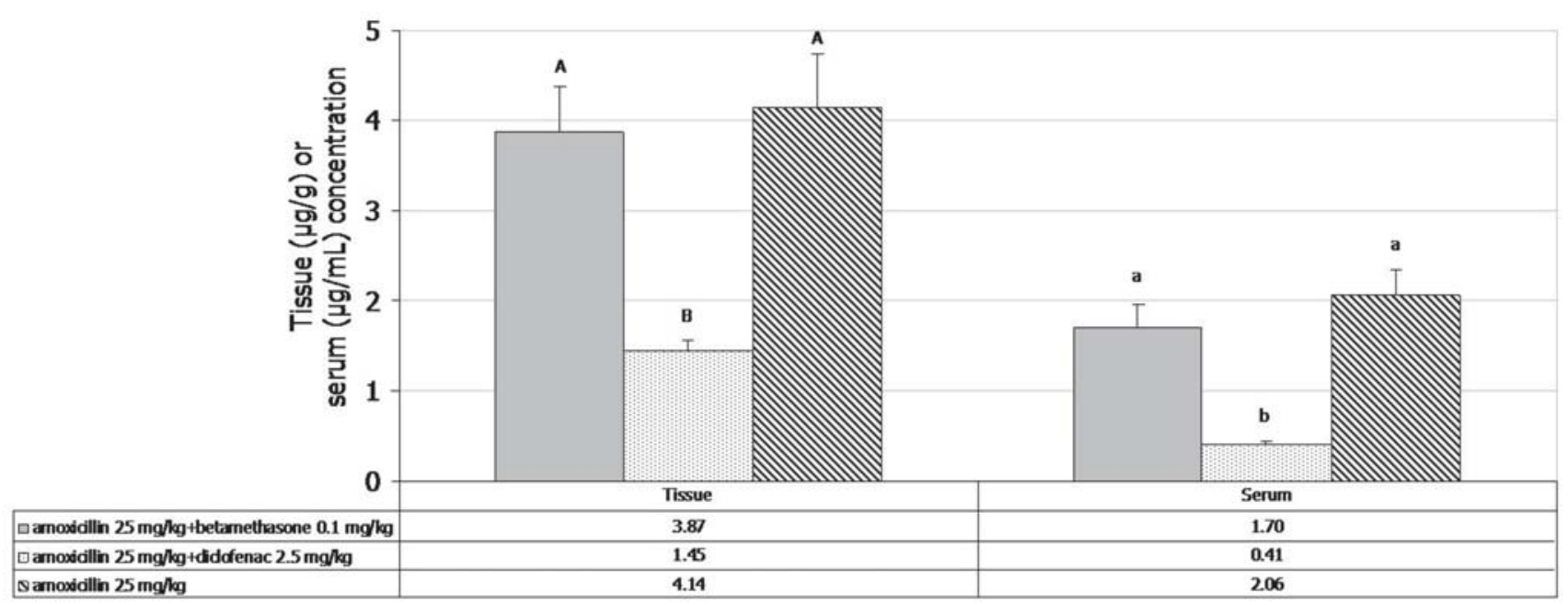

FIGURE 1- Amoxicillin serum and tissue concentrations (mean \pm s.e.m.) considering groups 1, 4 and 5. Groups 2,3 and 6 did not show any inhibition zone considering both serum and tissue samples. Different letters mean statistically significant differences $(p<0.05)$ among groups, considering serum and tissue concentrations separately 
previous studies, the microbiological method was accurate enough to measure amoxicillin concentrations in this study ${ }^{12}$. This method has the same precision as HPLC assay ${ }^{17}$ and it has been widely used for determining amoxicillin concentration ${ }^{5}$.

According to Groppo, et al. ${ }^{12}$ (2000), the period of 7 days used for the development of granulomatous tissue in the present study is adequate. These authors observed that different periods (7, 14, 21 and 28 days) for development of granulomatous tissues in rats did not interfere with the pharmacokinetics of amoxicillin.

The high anti-inflammatory activity of betamethasone and diclofenac sodium in both humans ${ }^{2}$ and rats ${ }^{24}$ was previously demonstrated. However, both anti-inflammatory agents with or without amoxicillin were unable to reduce tissue wet weights in the present model. Probably, the chosen model, i.e., chronic inflammatory granulomatous tissue, was not adequate to study anti-inflammatory properties. In addition, a single dose could not be enough to significantly reduce the inflammatory cells reflecting in a lower wet weight of the granulomatous tissues.

Another factor that could contribute to this nonsignificant anti-inflammatory activity is time. A previous study ${ }^{11}$ showed a significant reduction in the wet weight of granulomatous tissues in rats after six hours of diclofenac sodium administration ( $2.5 \mathrm{mg} / \mathrm{kg} / \mathrm{i} . \mathrm{m}$.) and probably 90 minutes (used at the present study) was not enough to observe significant reduction in wet weight.

The results of the present study corroborate with previous findings ${ }^{12}$ that showed great reduction in serum and tissue amoxicillin concentrations caused by diclofenac sodium. These authors observed that the drug interaction was probably not caused by metabolism or excretion interferences, since amoxicillin and diclofenac have different pharmacokinetics (plasmatic protein binding, excretion and metabolism). These same considerations about diclofenac could be applied to betamethasone.

In the present study, betamethasone did not interfere with serum or tissue concentration of amoxicillin when compared with the group in which amoxicillin was administered alone. This finding is important since the serum concentration of amoxicillin must be clinically significant considering prophylactic use of this antimicrobial agent ${ }^{2}$.

While amoxicillin has intestinal absorption through passive diffusion ${ }^{15,26}$ and through oligopeptide transporter system present mainly in kidney and intestine ${ }^{18}$ the absorption of diclofenac occurs mainly through excretion in the bile ${ }^{20}$. There are no data regarding the association between peptide transporters and diclofenac absorption. However, other drugs that have a high affinity for peptide transporters, like amiloride ${ }^{30}$ caused high decreases in amoxicillin concentration.

Thus, diclofenac could cause a reduction in the amoxicillin absorption. Steroidal agents were not associated with the same oligopeptide transporter system that is responsible for amoxicillin absorption ${ }^{18}$, which could explain the absence of drug interactions between both agents.

It was concluded that betamethasone did not affect the serum and tissue amoxicillin concentrations but diclofenac sodium significantly reduced them.

\section{ACKNOWLEDGEMENTS}

The authors thank CAPES for financial support and Mr. Jorge Valério for his assistance in the manuscript preparation.

\section{REFERENCES}

1- Agarwal G, Awasthi S, Kabra SK, Kaul A, Singhi S, Walter SD. Three day versus five day treatment with amoxicillin for non-severe pneumonia in young children: a multicentre randomised controlled trial. BMJ. 2004;328:791.

2- Alexander RE, Throndson RR. A review of perioperative corticosteroid use in dentoalveolar surgery. Oral Surg Oral Med Oral Pathol Oral Radiol Endod. 2000;90:406-15.

3- Baglie S, Groppo FC, Mattos-Filho TR. Tissue pharmacokinetic of amoxicillin. An experimental design in rats. Braz J Infect Dis. 2000;4:197-203.

4- Bantar C, Nicola F, Fernandez Canigia L, Arenoso HJ, Soutric J, Montoto M, et al. A pharmacodynamic model to support a 12-hour dosing interval for amoxicillin/sulbactam, a novel oral combination, in the treatment of community-acquired lower respiratory tract infections. J Chemother. 2000;12:223-7.

5- Charles BG, Chulavatnatol S. Simple analysis of amoxicillin in plasma by high performance liquid chromatography whit internal standardization and ultraviolet detection. Biomed Chromatogr. 1993; $7: 204-7$

6- Dajani AS, Bawdon RE, Berry MC. Oral Amoxicillin as prophylaxis for endocarditis: what is the optimal dose? Clin Infect Dis. 1994;18:157-60.

7- Dajani AS, Taubert KA, Wilson W, Bolger AF, Bayer A, Ferrieri P, et al. Prevention of bacterial endocarditis: recommendations by the American Heart Association. J Am Dent Assoc. 1997;128:1142-51.

8- Garbutt JM, Goldstein M, Gellman E, Shannon W, Littenberg B. A randomized, placebo-controlled trial of antimicrobial treatment for children with clinically diagnosed acute sinusitis. Pediatrics. 2001;107:619-25.

9- Georgopoulos A, Borek M, Ridl W. Randomized, double-blind, double-dummy study comparing the efficacy and safety of amoxycillin $1 \mathrm{~g}$ bd with amoxycillin $500 \mathrm{mg}$ tds in the treatment of acute exacerbations of chronic bronchitis. J Antimicrob Chemother. 2001,47:67-76.

10- Gordon RC, Regamey C, Kirby WMN. Comparative clinical pharmacology of amoxicillin and ampicillin administered orally. Antimicrob Agents Chemother, 1972;1:504-7.

11-Groppo FC, Mattos-Filho TR, Del-Fiol FS. Bioassay of amoxicillin in rats. Biol Pharm Bull. 2000;23:1033-5.

12- Groppo FC, Simões RP, Ramacciato JC, Rehder V, Andrade ED, Mattos-Filho TR. Effect of sodium diclofenac on serum and tissue concentration of amoxicillin and on staphylococcal infection. Biol Pharm Bull, 2004;27:52-5. 
13- Huisman-de-Boer JJ, van den Anker JN, Vogel M, Goessens WH, Schoemaker RC, Groot R. Amoxicillin pharmacokinetics in preterm infants with gestational ages of less than 32 weeks. Antimicrob Agents Chemother. 1995;39:431-4.

14- Koneman EW, Allen SD, Janda WM, Schreckenberger PC, Winn WC Jr. Color atlas and textbook of diagnostic microbiology. Philadelphia: J.B. Lippincott Company; 1997.

15- Margarit F, Moreno-Dalmau J, Obach R, Peraire C, Pla-Delfina JM. Intestinal absorption kinetics of a series of aminopenicillins and azidocillin. A comparative study in the rat. Eur J Drug Metab Pharmacokinet. 1991;3:102-7.

16- Martindale W. The Extra Pharmacopoeia. 31th ed. London: Royal Pharmaceutical Society Press, 1996. p. 125-9.

17- Moore TD, Horton R, Utrup LJ, Miller LA, Poupard JA. Stability of amoxicilin-clavulanate in bactec medium determined by highperformance liquid chromatography and bioassay. J Clin Microbiol. 1996;34:1321-2.

18- Moore VA, Irwin WJ, Timmins P, Chong S, Dando SA, Morrison, RA. A rapid screening system to determine drug affinities for the intestinal dipeptide transporter 1: system characterization. Int J Pharm. 2000;210:15-27.

19- Park SN, Yeo SW. Effects of antibiotics and steroid on middle ear mucosa in rats with experimental acute otitis media. Acta Otolaryngol. 2001;121:808-12.

20 - Peris-Ribera JE, Torres-Molina F, Garcia-Carbonell MC, Aristorena JC, Pla-Delfina JM. Pharmacokinetics and bioavailability of diclofenac in the rat. J Pharmacokinet Biopharm. 1991;19:647-65.

21- Plant JE, Higgs GA, Easmon CSF. Effects of anti-inflammatory agents on chronic Salmonella typhimurium infection in a mouse model. Infect Immun. 1983;42:71-5.

22- Prevot MH, Jehl F, Rouveix B. Pharmacokinetics of a new ora formulation of amoxicillin. Eur J Drug Metab Pharmacokinet. 1997;22:47-52.

23- Rodriguez AF, Kaplan SL, Hawkins EP, Mason E Jr. Effect of dexamethasone or hwa-138 in combination with antibiotics in experimental haemophilus influenzae type b infection. Antimicrob Agents Chemother.1991;35:1980-4.

24- Scholer DW, Ku EC, Boettcher I, Schweizer A. Pharmacology of diclofenac sodium. Am J Med. 1986;80:34-8.

25- Siaperas P, Pefanis A, Iliopoulos D, Katsarolis I, Kyroudi-Voulgari A, Donta I, et al. Evidence of less severe aortic valve destruction after treatment of experimental staphylococcal endocarditis with vancomycin and dexamethasone. Antimicrob Agents Chemother. 2001;45:3531-7.

26- Sugawara M, Saitoh H, Iseki K, Miyazaki K, Arita T. Contribution of passive transport mechanisms to the intestinal absorption of betalactam antibiotics. J Pharm Pharmacol. 1989;42:314-318.

27- Terada T, Saito H, Mukai M, Inui KI. Recognition of beta-lactam antibiotics by rat peptide transporters, PEPT1 and PEPT2, in LLCPK1cells. Am J Physiol. 1997;273:706-11.

28- Van Pelt LF. Ketamine and xylazine for surgical anesthesia in rats. J Am Vet Med Assoc. 1977;171:842-4.

29- Verba V, Sakiniene E, Tarkowski A. Beneficial effect of glucocorticoids on the course of haematogenously acquired Staphylococcus aureus nephritis. Scand J Immunol. 1997;45:282-6.
30- Westphal JF, Brogard JM, Jehl F, Carbon C. Assessment of the role of enterocyte ion exchange in the intestinal absorption of amoxicillin, based on a study of the interaction with amiloride. Pathol Biol.1995;43:590-5

31- Yoshizumi OM, Lee GC, Equi RA, Kim IT, Pitchekian-Halabi H, Adamu SA, et al. Timing of dexamethasone treatment in experimental Staphylococcus aureus endophthalmitis. Retina. 1998;18:130-5. 